\title{
Clashing deities in the book of Judith: A Greimassian perspective
}

\begin{tabular}{|c|c|}
\hline \multicolumn{2}{|c|}{$\begin{array}{l}\text { Author: } \\
\text { Risimati S. Hobyane }^{1}\end{array}$} \\
\hline \multicolumn{2}{|c|}{$\begin{array}{l}\text { Affiliation: } \\
{ }^{1} \text { School of Biblical Studies and } \\
\text { Ancient Languages, Faculty } \\
\text { of Theology, North-West } \\
\text { University, Potchefstroom } \\
\text { Campus, South Africa }\end{array}$} \\
\hline \multicolumn{2}{|c|}{$\begin{array}{l}\text { Note: } \\
\text { This article is based } \\
\text { on chapter four of the } \\
\text { researcher's PhD thesis, } \\
\text { completed in } 2012 \text { at the } \\
\text { North-West University } \\
\text { (Potchefstroom Campus) } \\
\text { under the supervision of Prof. } \\
\text { P.J. Jordaan. }\end{array}$} \\
\hline \multicolumn{2}{|c|}{$\begin{array}{l}\text { Correspondence to: } \\
\text { Risimati Hobyane }\end{array}$} \\
\hline \multicolumn{2}{|c|}{$\begin{array}{l}\text { Email: } \\
\text { risimati.hobyane@nwu.ac.za }\end{array}$} \\
\hline \multicolumn{2}{|c|}{$\begin{array}{l}\text { Postal address: } \\
\text { PO Box 9011, Promosa, } \\
\text { Potchefstroom 2530, } \\
\text { South Africa }\end{array}$} \\
\hline \multicolumn{2}{|c|}{$\begin{array}{l}\text { Dates: } \\
\text { Received: } 19 \text { Jan. } 2015 \\
\text { Accepted: } 27 \text { Mar. } 2015 \\
\text { Published: } 20 \text { July } 2015\end{array}$} \\
\hline \multicolumn{2}{|c|}{$\begin{array}{l}\text { How to cite this article: } \\
\text { Hobyane, R.S., 2015, } \\
\text { 'Clashing deities in the book } \\
\text { of Judith: A Greimassian } \\
\text { perspective', HTS Teologiese } \\
\text { Studies/Theological Studies } \\
\text { 71(3), Art. \#2893, } 8 \text { pages. } \\
\text { http://dx.doi.org/10.4102/ } \\
\text { hts.v71i3.2893 }\end{array}$} \\
\hline \multicolumn{2}{|c|}{$\begin{array}{l}\text { Copyright: } \\
\text { C 2015. The Authors. } \\
\text { Licensee: AOSIS } \\
\text { OpenJournals. This work is } \\
\text { licensed under the Creative } \\
\text { Commons Attribution } \\
\text { License. }\end{array}$} \\
\hline \multicolumn{2}{|l|}{ Read online: } \\
\hline 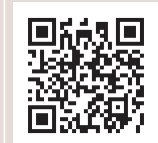 & $\begin{array}{l}\text { Scan this QR } \\
\text { code with your } \\
\text { smart phone or } \\
\text { mobile device } \\
\text { to read online. }\end{array}$ \\
\hline
\end{tabular}

The shaping of a text with a specific kind of plot is suggestive of the fundamental values that the author desires to either promote or discourage within the reader's community and its worldview. The Judith narrative is not an exception to this claim or rule. Scholars have contributed much in establishing the underlying purpose of Judith and came up with intuitive contributions to the field of study. However, the investigation of the overarching fundamental values that generated the story of Judith remains a gap to be filled in Judith research. The goal of this article is to fill this gap by investigating the fundamental values that the author desires to promote or discourage within the community, using the thematic analysis of the Greimassian semiotic approach. Subsequently, the present article reveals that the Judith narrative was designed to be an ideological vehicle in its intent, aimed at rejuvenating and revitalising the core values of the Jewish religion during the difficult times of the Second Temple period.

\section{Introduction}

The book of Judith ${ }^{1}$ is a work of fiction (Efthimiadis-Keith 2004:15, 153). This work of fiction, however, remains a literary text before us and it deserves to be approached with respect and be appreciated as it is. Narratives do not have to be historically true to have an impact on the community in either a positive or a negative way. Therefore some overarching questions around the Judith narrative should be addressed. For example: What is the intended purpose of this work of fiction (Judith)? What were the probable religious challenges that the author of this fictional text sought to address in the home community? In which time or period is this fictional text set?

Judith consists of two halves, traditionally called Part I (ch. 1-7) and Part II (ch. 8-16) (Jordaan 2009a:180). Part I is the story of a developing religious crisis facing Israel (Nickelsburg 2005:97), and Part II is the story of how God saves Israel at the hand of a woman, Judith (Harrington 1999:27). For the purpose of this article, these two parts of Judith are further demarcated into four episodes relating to the thematic path or the circulation of values across the narrative. The episodes are as follows:

- Episode A (ch. 1-3, 7:1-8 and 11:1-8): This episode narrates the dominance of the Assyrian cult $^{2}$ and its possible installation as an alternative religion for all the people.

- Episode B (ch. 4:1-15): A narration of the resistance showed by the Jewish community against the evil plan of Nebuchadnezzar.

- Episode C (ch. 5:1-6:21 and 8-13:5): This is a narration of the Assyrian army's continuation to put pressure on the Jewish community to surrender their cities and sacred places.

- Episode D (ch. 13:6-16:25): It is a narration of how the attempt by the Assyrians to replace the Jewish religion with the Assyrian cult fails as Judith beheads Holofernes.

These four episodes will be discussed in detail later in this article.

Scholars have brought forward various opinions concerning the date of authorship of Judith. ${ }^{3}$ Efthimiadis-Keith (2004:8) argues that the overall ambience of the book reflects the post-exilic era and setting, which is the Persian Era (6th-4th century), Early Maccabean Era (168-135), and the Hasmonean Era (135-63). While acknowledging the difficulty around determining the exact date of the setting in Judith, this article, agreeing with Efthimiadis-Keith (2004:19), takes into serious consideration the fact that Judith reflects a political-religious crisis in which

\footnotetext{
1.The book Judith is referred to in italics (Judith), and the character Judith in normal font (Judith).
}

2.Cf. Hobyane (2012:96) for the choice of referring to the Assyrian movement as a cult. This is done to make a clear distinction between the Jewish faith and the Assyrian faith

3.The present study takes note of various opinions regarding the nature (historical fact or fiction) and the date of authorship of the story of Judith. However, it is outside the scope of this article to do an in-depth study concerning these matters. Some scholars have already toiled fruitlessly on these matters, and still we do not have definite answers, only speculations. See also various opinions on the date of Judith discussed in Efthimiadis-Keith (2004:22). 
the faithful are threatened by the onslaught of a foreign nation. Efthimiadis-Keith (2004:19) further argues that many scholars have correctly observed that this kind of crisis is most easily accommodated within the Hellenistic period ${ }^{4}$ of Jewish history.

\section{Problem statement}

Very notable in the Judith narrative is the clash of deities, namely Nebuchadnezzar (the self-proclaimed, god and king of Assyria) and the God of Israel, as Harrington (1999:28) also observes. Hobyane (2014:896) observes that a research survey on Judith shows that this narrative has received noteworthy attention from various scholars who employed various approaches to investigate its meaning, significance, ethical stance and purpose. While many scholars wrestle with the fictitious and war or violent character of the narrative, this is all they begin and end with in their analysis of Judith.

The intention of this article is to fill this gap in the Judith research by going beyond its fictitious or violent character to investigate the overarching fundamental values that generated this fiction, by using the Greimassian approach to narrative texts.

Narratives (fictions or real stories) are written to propagate ideologies in the concerned community of a particular period. The central hypothesis here is that the application of the thematic analysis of the Greimassian approach reveals that Judith is a story with a clear didactic intent, whereby the author wants to propagate and discard certain core values within the Jewish religion during the Second Temple period.

The contribution is unique in the sense that, instead of following the historical critical route of narrative analysis, it employs a Greimassian semiotic approach that accepts, appreciates and analyses a story as a whole without discrediting any of its parts (cf. also Hobyane 2014:898).

\section{The approach of analysis}

The Greimassian semiotic approach to literary texts is an approach that focuses on exploring semiotic objects at three different levels of analysis: the figurative, the narrative and the thematic (Kanonge 2009:27-31).

This article focuses on the third of the three levels of analysis of the Greimassian approach, namely the thematic analysis. While the figurative analysis focuses on figures or characters in the narrative (Everaert-Desmedt 2007:30) and the narrative analysis examines the organisation of a text as discourse, the thematic analysis (also called deep level of analysis) is concerned with the investigation of the fundamental values (e.g. love, freedom, equity, glory, faith, human right, etc.) that account for the generation of a text. These values are thereafter investigated syntagmatically by

4.While the antecedents of the movement occurred long before, the Hellenistic Age is seen by most to have begun in 323 with the death of Alexander, and to have continued until 30 (Elwell \& Comfort 2001:n.p.). means of the thematic itinerary and presented on a semiotic square, which is the main tool for investigation at this level. This mechanism serves first to classify values in Judith, and second to track their trajectory throughout the narrative. The syntagmatic perspective is concerned with the circulation of values across the text (Kanonge 2009:57). ${ }^{5}$

In summary, the focus of the thematic analysis employed in this article is on the following aspects: opposition of values in the story; ${ }^{6}$ and the thematic itinerary. ${ }^{7}$ There is, however, a third aspect under the thematic analysis, namely the veridictory square, ${ }^{8}$ whose focus is beyond the aim of this article.

\section{The opposition of core values in Judith}

In the analysis of meaning, semiotics proceeds from the recognition of differences in the narrative and the definition of the relationships underpinning it (Martin \& Ringham 2000:116). Semiotics postulates that opposition gives rise to the meaning. Kanonge (2009:176) states that the paradigmatic use of the semiotic square in the thematic level depends on results from the preceding steps of analysis, that is, figurative and the narrative steps.

When doing the discursive or figurative and the narrative analyses, Hobyane (2012:155-158) establishes that there are notable oppositions between the Jewish religion, propagated by Judith, and the Assyrian cult, promoted by Holofernes. The central concern here is that the Jewish religion (with its values) is about to be destroyed and substituted by the Assyrian cult, which also has its own value systems (later called anti-values). In the ancient mind set, the god of the conqueror was the strongest. People even merged deities of the conqueror with those of the conquered and called them by joint names. In the context of Jewish religion, however, the merging of deities was not acceptable. The Jewish God is exclusive. These oppositions are extracted and placed in their positions in Table 1. The table is a representation of the opposition of core values focusing on both Judith (Jewish religion) and Holofernes (Assyrian cult). Furthermore, the table is a representation of values in terms of two main oppositions in the story, that is, religious affiliation and ethnicity or nationality.

In summary, the two oppositions proposed are demarcated as follows: Oppositions based on religious affiliation are

5.The Paradigmatic use of a semiotic square classifies values according to the cultura axiology (good versus bad; acceptable versus not acceptable). It is important to note that the uses of the semiotic square are numerous. Mapping out opposed values is only one of these (Kanonge 2009:56).

6.In brief, opposition of values is recognition of the fact that the characters featured in the story hold different viewpoints or convictions about their religion and ethnicity (Martin \& Ringham 2000:116).

7.This is the process of tracking the trajectory of opposing values in the story from the initial state to the final state (Kanonge 2009:182).

8.The term veridiction designates the process of truth-telling in a story (Martin \& Ringham 2000:139). Hobyane (2012:143) further indicates that veridiction enables a reader to determine the truth that the author desires to convey and the falsehood he wishes to oppose or expose. 
TABLE 1: Main opposition of values in the Judith narrative, in terms of religion and ethnicity.

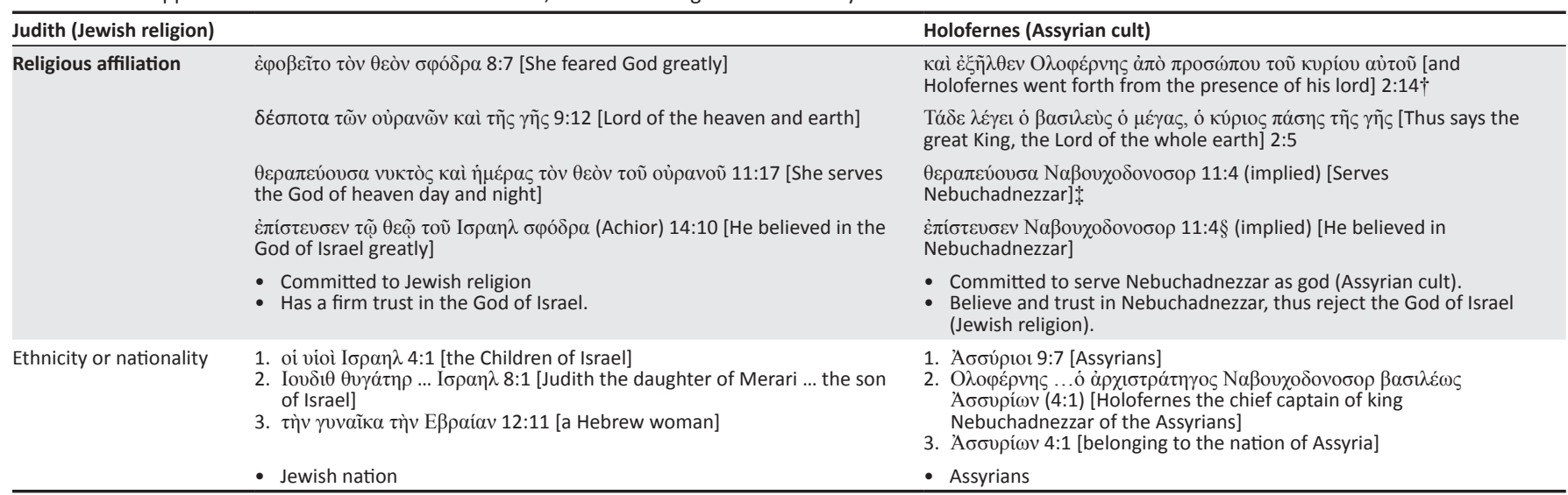

$\dagger$, This Greek sentence shows that Holofernes's obedience to his god and master entails reverence with a religious connotation.

\$, In 11:4, Holofernes classifies himself under the group of people who serve Nebuchadnezzar.

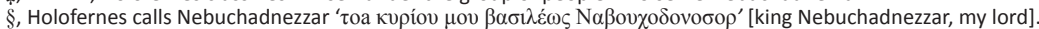

established between the members of the Jewish religion (where Judith and Achior are good models) and the Assyrian cult (Holofernes is the model here). In 4:12 the text reveals that the Jewish religion has the Lord God of Israel (Kúpı๖ ó $\theta \varepsilon o ̀ \varsigma$ I $\sigma \rho \propto \eta \lambda)$ as God and the Assyrian cult has Nebuchadnezzar

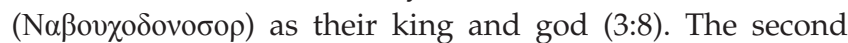
opposition is based on ethnic or nationality difference. This article recognises the exception of people like Achior in the narrative. Even though he is not a Jew by birth, he is added to the house of Israel by virtue of faith in God (Roitman 1992:31; cf. Grabbe 2004:167). The same cannot be argued concerning Holofernes and other characters. The oppositions are tabled (Table 1) according to the sequence of their occurrence in the narrative.

Table 1 reveals that Judith comprises of two main categories of oppositions of values, namely oppositions based on religious affiliation on the one hand, and oppositions based on ethnicity or nationality on the other. Oppositions related to religious affiliation are discussed below.

\section{Opposition of core values in terms of religious affiliation}

The first category of opposing core values, based on the religious affiliations (Jewish religion versus Assyrian cult), can be placed on the semiotic square as presented in Figure 1.

This article contends that religion is the main object of quest in Judith. The existence of the two religious affiliations seems to provide the spark of the conflict, and consequently the clash of deities. In describing the story of Judith, DeSilva (2002:85) argues that it is the contest between Gentiles, with their claims about gods and the God of Israel. He further states that this is a prominent dynamic that runs through the history of Israel from the Exodus through to the Second Temple period. The semiotic square (Figure 1) depicts the core values of the Jewish people (led by Judith) against that of the Assyrians under the leadership of Holofernes. The values outlined in the semiotic square depend entirely on the religious affiliation of the people.

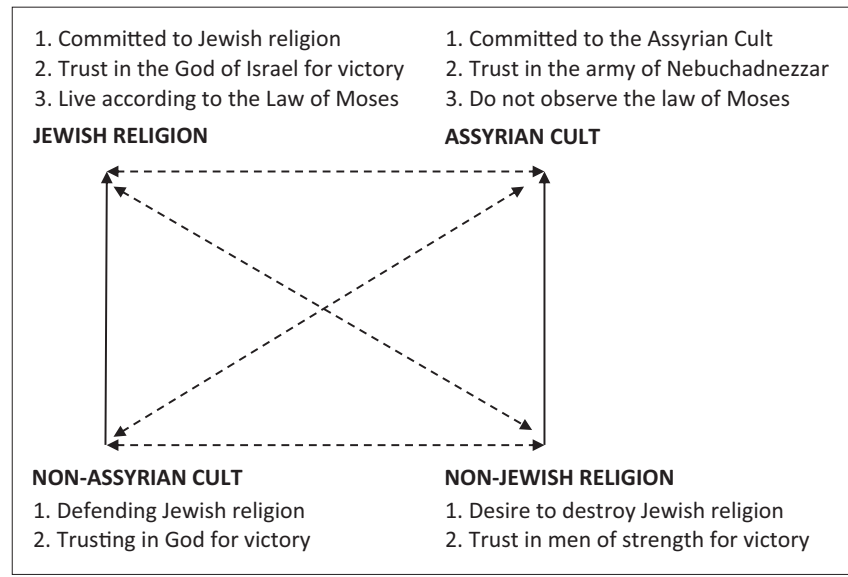

Source: Courtes, J., 1991, Analyse semiotique du discours: De l'enonce a l'enonciation Hachette, Paris; Courtes, J., 1995, Du lisible au visible, De Boeck University, Bruxelles; Henault, A., 1983, Narratologie semiotique generale: Les enjeux de la Semiotique 2, Presses Universitaires de France, Paris

FIGURE 1: Illustrating opposition of values in Judith based on religious affiliations.

\section{Opposition of core values in terms of ethnicity}

The second category of opposing core values, based on ethnicity or nationality (Jewish people versus Assyrians) can stand on the semiotic square as presented in Figure 2.

Ethnicity or nationality issues in the Judith narrative seem unavoidable. The question of non-Jewishness in Judith is simple: it is the Jews, the covenantal people of God, against the Assyrians (Kaiser 2004:39).

The opposing core values in the narrative are based on the rivalry between these two nations: the Assyrians under the arrogant leadership of Nebuchadnezzar and the Israelites trusting in their God for survival. While discussing the role of the Lord God of Israel (Kúpı Israel's identity during the Second Temple period, Wohrle (2011:153) states that only He is able to change the situation of his people, to nullify the threat of the nations, to protect the people against new assaults, and to lead them to new prosperity. 


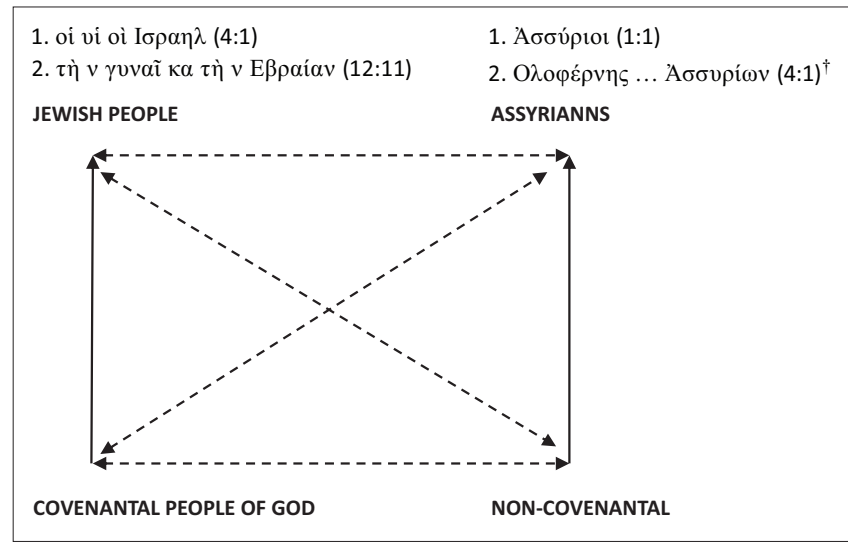

Source: Courtes, J., 1991, Analyse semiotique du discours: De l'enonce a l'enonciation Hachette, Paris; Courtes, J., 1995, Du lisible au visible, De Boeck University, Bruxelles; Hachette, Paris; Courtes, J., 1995, Du lisible au visible, De Boeck University, Bruxelles; Universitaires de France, Paris

$\dagger$, Both Holofernes and Nebuchadnezzar are identified as citizens of Assyria.

FIGURE 2: Semiotic square illustrating opposition of values in Judith, based on ethnicity.

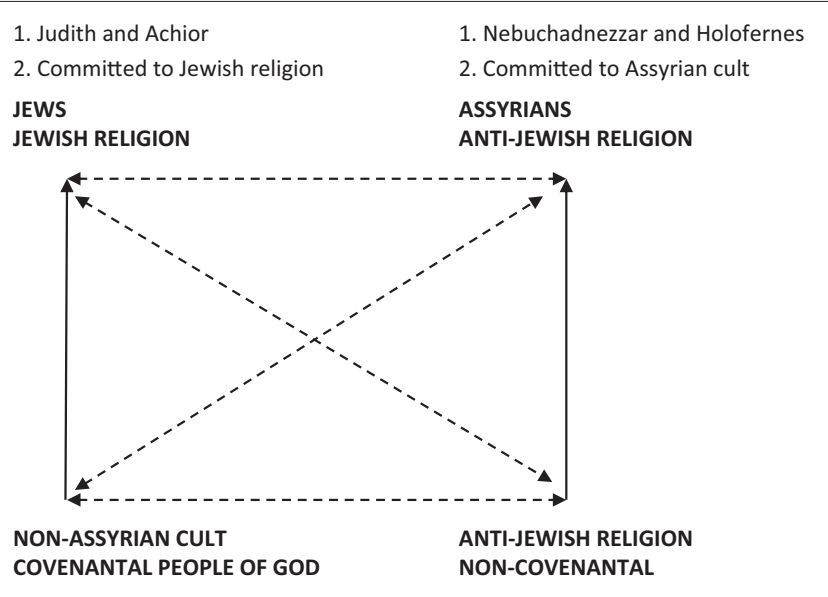

Source: Courtes, J., 1991, Analyse semiotique du discours: De l'enonce a l'enonciation Source: Courtes, J., 1991, Analyse semiotique du discours: De l'enonce a l'enonciation, Henault, A., 1983, Narratologie semiotique generale: Les enjeux de la Semiotique 2, Presses Henault, A., 1983, Narratologie
Universitaires de France, Paris

FIGURE 3: Semiotic square illustrating the opposition of values in Judith, based on ethnicity or nationality and religious affiliation.

Putting together religious affiliation and ethnicity or nationality in the semiotic square, the schematic representation can be seen as presented in Figure 3.

As shown in Figure 3, the opposition based on ethnicity and religion is key to understanding and interpreting Judith fairly. It is evident that Judith seeks to call on the Jews of the Second Temple period and all who believe in the God of Israel to defend the existence of the Jewish religion and its core values. The Jews here are called upon to guard against the extinction of the Jewish religion by foreign cults.

The foreign cult in this instance is the Assyrian cult. The latter is viewed as a threat to Jewish identity. In fact, Dor (2011:173) states that Jewish identity of the postexilic congregation is one of the central issues in the recent research on the late biblical period. This is seemingly associated with the current worldwide problem of national identity versus the trends of globalisation and of multinational societies. The purpose and main message of Judith seems to be very much in line with Dor's findings.

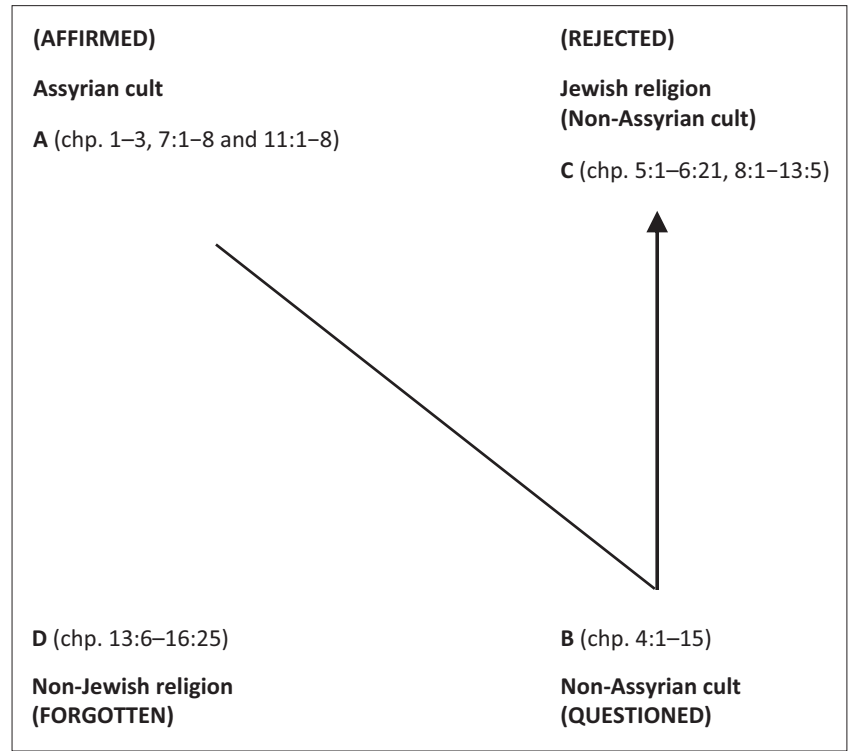

Source: Everaert-Desmedt, N., 2007, Semiotique du recit, De Boeck, Bruxelles FIGURE 4: Semiotic square illustrating the circulation of anti-values (anti-Jewish religion).

In brief, this section discussed opposition of values in Judith. It has been established that oppositions are based on religion and ethnicity or nationality. The following section discusses the thematic itinerary of values in Judith.

\section{The thematic itinerary}

The first dimension of the thematic analysis focuses only on the classification of opposing values according to the Jewish culture and ideology. The second step is called a syntagmatic perspective. It uses the semiotic square, not only to classify values, but to track their trajectory in the story from the initial state to the final state (Kanonge 2009:182). In other words, the concern here is to see which values the story seeks to reject, and which it seeks to maintain. According to Kanonge (2009:182) the circulation of values defines the ideology that the narrative seeks to establish or overthrow. The itinerary of commendable values generally completes the course and the itinerary of non-commendable values stops halfway.

As already shown above (Figure 3), the Judith narrative comprises two opposing camps with regard to religious affiliation. The Assyrian camp, on the one hand, represents a religious ideology that is associated with terror (4:2), destruction (3:1-10), idolatry (3:8) and sexual immorality (12:12) and Nebuchadnezzar is a god of this cult. Wennel (2007:68), on the other hand, argues that the essence of the Jewish faith lies in the fact that they are the covenantal people of God (4:1). ${ }^{9}$ They are expected to hope in and be faithful to Yahweh (8:17), call unto him for help (4:9,12 and 15), keep the laws of Moses and remain pure before the Lord (12:6-10 and 13:16). The Assyrians seem to overlook these values and way of life. They aim to overthrow these values and replace them

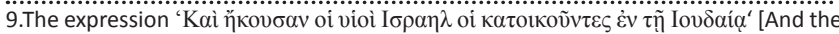
children of Israel who dwell in Judaea heard ...] in $4: 1$ undoubtedly introduces the

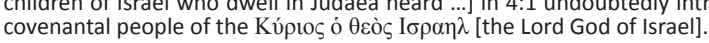


with the Assyrian way of life (anti-Jewish religion). While the Jews (led by Judith) on the other hand are determined to defend their religious values and prove that the God of Israel is the one and only true God, not Nebuchadnezzar.

Unless a reader chooses to ignore the textual evidence listed above, the Assyrian cult and Jewish religious belief are two main opposing ideologies in the Judith narrative. The investigation of the circulation of values follows focusing on the two main parts of the story, that is Part I (ch. 1-7) and Part II (ch. 8-16), which can be further divided into distinct episodes. The following part of the article is dedicated to briefly discussing the itinerary of these opposing values in Judith.

\section{Assyrian cult (anti-Jewish religion)}

The narrative presents the Assyrian cult as the possible alternative religion for the Jewish people. Nebuchadnezzar, king of Assyria, sends from his capital city, Nineveh, his chief general, Holofernes, with a mighty army to take revenge on all the people who refused to submit to him. Nebuchadnezzar orders his army general to destroy all the gods of the land, so that all nations might worship Nebuchadnezzar as god (Enslin 1972:7).

Nebuchadnezzar and his army general, Holofernes, are introduced in the narrative as destructive, merciless and cruel leaders (ch. $1-3 ; 5: 22-6: 13 ; 7: 1-8 ; 11: 1-8$ ). They are a symbol of terror that will evoke God's protective power over Israel and the Jewish religion (Hobyane 2012:50).

The circulation of these anti-values is discussed following the episodes demarcation provided in the introduction and can be summarised on the semiotic square presented in Figure 4.

\section{Assyrian cult affirmed}

The first three chapters of Judith narrates the plan of Nebuchadnezzar to wage war against Arphaxad to bring him under subjection and the marches of Holofernes against the western countries, including Israel, which refused to become his allies (Harrington 1999:27). It is in these chapters where the reader learns more about Nebuchadnezzar and Holofernes' cruelty and their determination to destroy other nations and their local gods. The text reports the main reason why these nations must be destroyed in 3:8 when it says:

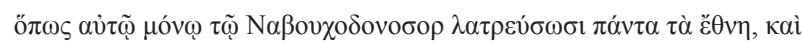

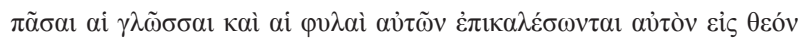
[all nations should serve Nebuchadnezzar alone, and that all their dialects and tribes should call upon him as a god].

Nebuchadnezzar is determined to install the Assyrian cult as an alternative religion for all the people. According to Raja (1998:701) the second chapter brings out the high pretensions of Nebuchadnezzar; he is portrayed as making himself equal to Yahweh, 'the lord of the whole earth' (2:5; cf. also LXX Josh 3:11; Zech 6:5). At this point in the narrative, the Assyrian cult appears to be well on its way to being the only (alternative) religion for Nebuchadnezzar's victims.

\section{Assyrian cult questioned}

Chapter 4:1-15 of Judith narrates the resistance showed by the Jewish community against the evil plan of Nebuchadnezzar. Raja (1998:701) states that this chapter is a clear example of the dictum 'work as though everything depends on God and pray as though everything depends on you'. Hearing about the impending insurgence by Holofernes, Joachim, the high priest and the council of all the people of Israel in Jerusalem order their brethren in the north to take possession of the passage that leads to Judaea. The people appealed to God for help. Clearly, the Jewish community is not ready to give up their religious values and accept foreign cults. This refusal to surrender constitutes the rejection and the questioning of the alterity, i.e. the attempt to destroy the Jewish religion and have it replaced by the Assyrian cult.

\section{The Assyrian cult rejected}

Chapters 5:1-6:21 and 8-13:5 is the narration of how Holofernes and the Assyrian army continue to put pressure on the Jewish community to surrender their cities and sacred places. The modus operandi in this section is to silence those who speak the truth about the Jewish religion (e.g. Achior in chapter 5:1$6: 21),{ }^{10}$ starving the Israelites to death $(7: 7,12$ and 17) and to entice (seduce) their leaders (like Judith) to the Assyrian cult's way of life (12:1-9). Instead of submitting to the Assyrian way of life, Judith, as an observant Jew, keeps to the dietary (food) laws, secludes herself for prayer and follows the norms of ritual purification (Raja 1998:704). The fact that Achior, the people of Bethulia and Judith pass these tests implies that the trajectory of anti-values does not find its way to the end. The Israelites and their leaders, Judith in particular, are resolute about the defence of the Jewish religious values. After all the attempts made by Holofernes and his army, the Assyrian cult still did not succeed to overthrow the Jewish religion.

\section{The Assyrian cult is forgotten}

The fourth episode (13:6-16:25), according to Figure 4, suggests that the attempt by the Assyrians to replace the Jewish religion with the Assyrian cult fails as Judith beheads Holofernes. The Jewish religion survives extinction and emerges victoriously. The beheading of Holofernes and the defeat of the Assyrian army means that the anti-values (terror, destruction, idolatry and sexual immorality) of the Assyrian cult do not achieve a complete trajectory in Judith.

The defeat of the Assyrian army by the Israelites leads to the survival of the Jewish religion and the preservation of its core values. Subsequently, Nebuchadnezzar fails in his mission and the God of Israel is hailed as the true God, Who always protects his people.

In brief, the thematic path of the semiotic square (Figure 4) can be summarised as follows: The narrative starts with the affirmation of the Assyrian cult ('Assyrian cult affirmed'),

10.Achior is sentenced to death. He is bound and handed over to the people of Bethulia to be killed together with the Israelites when Holofernes attacks them. 
then proceeds to question it ('Assyrian cult questioned'). The situation in the third episode ('The Assyrian cult rejected') shows a complete rejection of the Assyrian cult values, and finally the Assyrian cult is forgotten. The essence of the situation in the final episode ('The Assyrian cult is forgotten') is that the Assyrian cult is no longer a threat to the existence of the Jewish religious values.

\section{Jewish religion}

In discussing the survival of the Jewish religion, Enslin (1972:1) concedes that the author of Judith wanted to instruct the Jewish people and to inflame the Judeans to stand against the assault on the Jewish religion. This is the second value to be discussed in this section. The investigation of the trajectory of this value is also conducted focusing on both parts of the narrative, which for the sake of clarity is organised into four sections (not necessarily episodes in the story).

The semiotic square representing these four sections appears in Figure 5.

The endeavour of this section is to discuss the circulation and the affirmation of the Jewish religious values in the Judith narrative, as proposed in Figure 5.

\section{Affirmation of the Jewish religion}

According to Kaiser (2004:40), the narration of chapter 4:1-15 raises the question whether the claim (true god) is appropriate

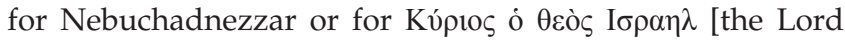
God of Israel]. This section of the narrative introduces the contest between the Jewish religious values and the Assyrian cult anti-values. Contrary to the Assyrians, who trust in Nebuchadnezzar as their god, the children of Israel trust in the God of Israel. The text indicates, in 7:9 that 'they cried to

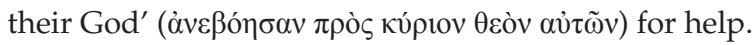

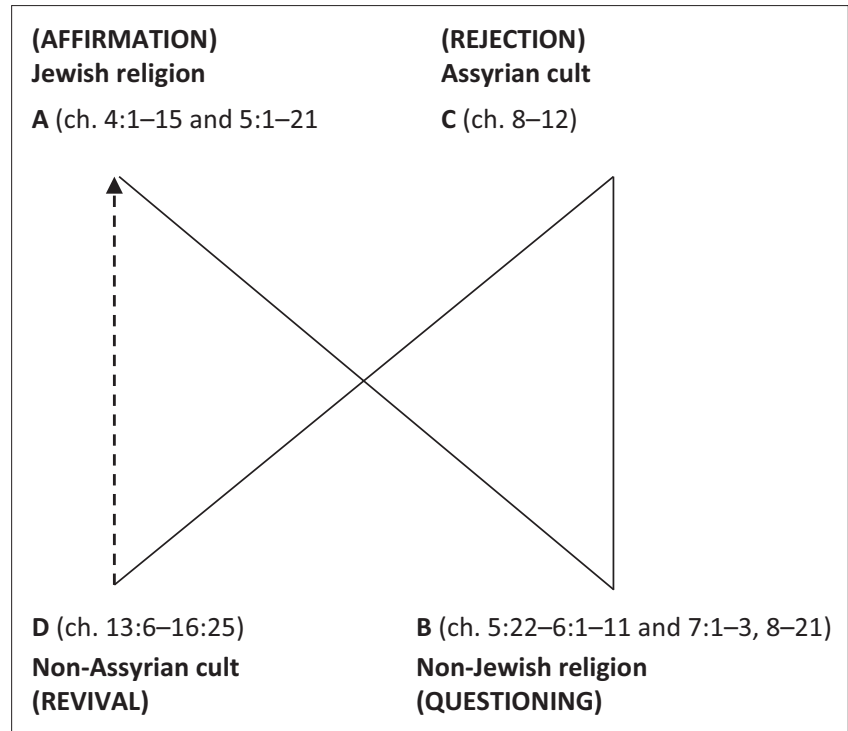

Source: Everaert-Desmedt, N., 2007, Semiotique du recit, De Boeck, Bruxelles

FIGURE 5: Semiotic square illustrating the circulation and the affirmation of values (Jewish religion) in the Judith narrative.
This is not strange of the children of Israel. It is their covenantal obligation to rely on the God of Israel in times of crisis. This can be judged as a good value. The effort to preserve the Jewish religion emerges as a strong opposition to the religious claim of Nebuchadnezzar (Assyrian cult). The resistance shown by the Israelites, since their introduction in chapter 4 , forms the central concern of the whole narrative. Judith seeks to make a call to the covenantal people of God of the Second Temple Period to guard against attempts by foreign religions to destroy the Jewish faith. This call seems to be obligatory to follow for any true Jewish religious believer.

\section{Jewish religion questioned}

Having made clear the position of the children of Israel, the story continues to highlight the pressure by the Assyrians (5:1-6:21; 8-13:5). The Assyrians, Holofernes in particular, are infuriated by the attitude shown by the Jews and the positive testimony of Achior about the Jewish religion. Holofernes'

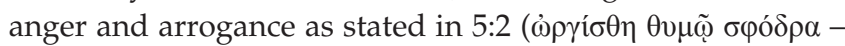
he was very angry) constitutes the questioning of the preservation of the Jewish religious values. Furthermore, when Achior concludes his testimony about the children

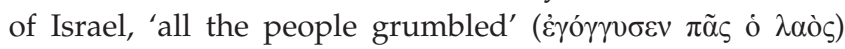
and demanded that Achior be killed. This continues to suggest that the anti-value of non-Jewish religious belief is propagated further by the Assyrians. Instead of receiving Achior's advice, Holofernes shows great interest in the advice of the children of Esau. In 7:16 the text records:

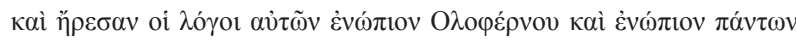

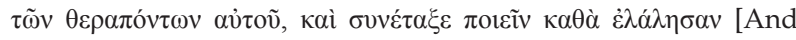
their (children of Esau) words pleased Holofernes and all his servants and he commanded to do as they had spoken].

The children of Esau are traditional enemies of Israel. They display an attitude of hatred to the children of Israel or against the Jewish religion. They are an anti-Israel and anticovenantal movement. The children of Esau promote values opposed to Jewish faith. At this stage Jewish religious values are questioned or threatened to be rejected.

This act of questioning the Jewish religious values extended in the narration by the evil treatment, which Holofernes exerted on the children of Israel. The Assyrian cult, at this stage, intensifies their mission of questioning the Jewish religion. A few examples from the text can be given: In 7:18 the text reports that the armies supporting Holofernes who camped around the Israelites were 'a very great multitude'

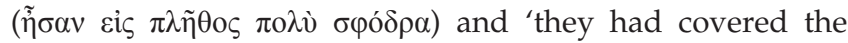

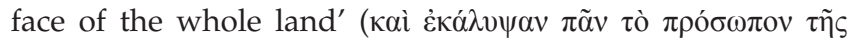
$\gamma \tilde{\eta} \varsigma)$. Here the author uses exaggeration to elevate the dominance of the Assyrians over the Israelites. As a result of the multitude of the Assyrians camping around them, the Israelites are discouraged. The text in 7:19 literally says,

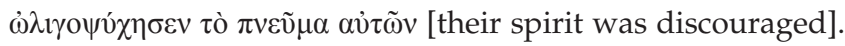
This discouragement suggests that the children of Israel do not see a way out from the impending destruction. 
In 7:21 the text further reports that the Jewish people are starving and have no water to drink. Consequently, their

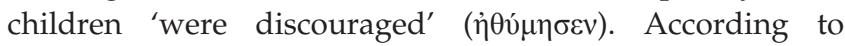
Swanson (1997) the word ' $\eta \theta \dot{\mu} \mu \eta \sigma \varepsilon v^{\prime}$ comes from the word ' $\alpha \theta v \mu \varepsilon \omega^{\prime}$ ', which can be translated as 'to be disheartened'. This word may also mean 'to become discouraged to the point that you lack motivation' (Louw \& Nida 1996). The lack of motivation among the children of Israel would mean that they have no courage to resist Holofernes and his plans. Following the narration of the discouragement among the children of Israel, is the compromising position taken by the elders of Bethulia. The elders of Bethulia are about to surrender the city and the sacred places.

\section{Rejection of the Assyrian cult}

Chapters 8 to 12 highlight the positive trajectory of the Assyrian cult's anti-values over the Jewish religion. The situation here consists of scenarios that suggest that nothing seems to stand in the way of the Assyrians conquering the children of Israel. Consequently, the Assyrian cult threatens to replace the Jewish religion. Judith has left Bethulia. The people back home continues to starve and they have no water to drink. The leadership in Bethulia has no answers to the situation. All they can do is to allow Judith to leave the camp with her undisclosed plan (8:35). Despair, terror and great uncertainty rule in Bethulia. Judith, a symbol of the true Jewish faith, is no longer with them, but in the Assyrian camp.

Furthermore, the Assyrian army sees the arrival of Judith in their camp as a triumph for the Assyrian cult. Her speech before the Assyrian patrol and later before Holofernes gives the impression that the Assyrian cult finally has everything under control (10:12-12:19). ${ }^{11}$ Judith's lies, flattery and ironic expressions intensify the feeling of victory in the Assyrian camp. Holofernes further places Judith under the care of his servant, Bagoas (12:11). Judith is exactly where Holofernes wants her to be. She has turned to be a property and a sexual object of Holofernes. ${ }^{12}$

The Assyrian cult, at this stage, seems to have everything under control. However, this trajectory does not follow through to the end of the narrative. Things are actually not the way they appear to be.

\section{Jewish religion prevails}

Chapters 13:6-16:25 of the narrative draw attention to the failure of the trajectory of the Assyrian cult's anti-values and the success of the preservation of the Jewish religious values. After the killing of Holofernes, the Assyrians are powerless and helpless, and therefore can no longer propagate their

11.It must be remembered that the speech of Judith before the Assyrian patrol and Holofernes has no truth in it. Hobyane (2012:70-76) discusses the significance of flattery, lies and irony in the speech of Judith.

12.Since Judith arrived at the Assyrian camp, the text makes clear in 12:16 that Holofernes' desire was to have sexual intercourse with her ( '

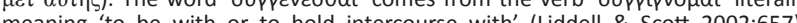
This word is used with a sexuat connotation in 12:16. Sinful desire and sexual This word is used with a sexual connotation in 12:16. Sinful desire and sexual immorality underlines and characterises a non-Jewish religious belief, and in this instance, these anti-values seemed to be totally under control. evil schemes against the Jewish religion. The Judith narrative seeks to reject the Assyrian cult's anti-values and maintain the values that are essential for the survival of the Jewish religion. The Jewish religion survives extinction. Jerusalem and the temple survive destruction. The thematic values of the Jewish religion complete its trajectory.

In summary, Kay (1913:247) suggests from the writing in Hebrew and from the detailed references to the geography of the Holy land, that the author was a Palestinian Jew. According to Efthimiadis-Keith (2011) Judith contains textual elements that link it with the Egyptian origin. Historical issues are of less importance in the Greimassian semiotic approach of analysis. The point here is that the author seems to be making a strong call to the Jews of the Second Temple period to oppose the extinction of the Jewish religious values. This ideology seems to be the central concern of the story and can be seen in the study of the thematic trajectory of the whole story, as discussed above. The trajectory of the promotion of the Assyrian cult (alterity) does not make a complete course in the narrative. However, the preservation of the Jewish religious values by the Jews (Judith in particular) completes its trajectory. Therefore, the thematic itinerary does not proceed to the non-Jewish religious belief to imply that the Assyrian cult succeeds in overthrowing the Jewish religion. In fact, the story ends contrary to the desire of Nebuchadnezzar.

In chapter 16 the story ends with a song of praise unto the God of Israel and a big celebration in Jerusalem. This song of praise is the acknowledgement of the intervention of Kúpıৎ̧ o $\theta \varepsilon o ̀ \varsigma ~ I \sigma \rho \alpha \eta \lambda$ (the Lord God of Israel) in preserving the Jewish religion. This celebration posits the appreciation of the conservation of the values that the author sought to campaign for with this story. Jordaan (2009b:331-342) also indicates that the Ammonites, women and slaves play a huge role in this regard.

\section{Conclusion}

This article investigated the overarching fundamental values that generated the story of Judith. As already mentioned above, the reader of Judith will notice that there is a fierce clash of deities in the story. Nebuchadnezzar (the selfproclaimed god and king of Assyria) intends to overthrow God (the God of Israel). Although scholars have done considerably well in investigating the meaning, significance, ethical stance and purpose of Judith, the question as to what generated this clash of deities in Judith, has not yet been extensively investigated. The main focus of this article was to attempt to fill this gap in the Judith research.

The investigation of the fundamental values that generated the story of Judith was carried out using the thematic analysis of the Greimassian approach. The investigation was mainly informed by two main tools of the approach of analysis, that is, the study or the classification of opposing values in the Judith narrative, using the semiotic square and the tracking of the trajectory of values in the story (the thematic itinerary). 
The examination revealed that oppositions in Judith are based on religion and ethnicity or nationality.

The trajectory of the promotion of the Assyrian cult (alterity) does not make a complete course in the narrative. However, the preservation of the Jewish religious values by the Jews (Judith in particular) completes its trajectory. Therefore the thematic itinerary does not proceed to the non-Jewish religious belief to imply that the Assyrian cult succeeds in overthrowing the Jewish religion. In fact, the story ends contrary to the desire of Nebuchadnezzar.

\section{Acknowledgements \\ Competing interests}

The author declares that he has no financial or personal relationships which may have inappropriately influenced him in writing this article.

\section{References}

Courtes, J., 1991, Analyse semiotique du discours: De l'enonce a l'enonciation Hachette, Paris.

Courtes, J., 1995, Du lisible au visible, De Boeck University, Bruxelles.

DeSilva, D.A., 2002, Introducing the apocrypha, Baker Academic, Grand Rapids, MI.

Dor, Y., 2011, 'The rite of the separation of the foreign wives in Ezra-Nehemiah', in O. Lipschits, G.N. Knoppers \& M. Oeming (eds.), Judah and the Judeans in the achaemenid period: Negotiating identity in an international context, pp. 173-188, Eisenbrauns, Warsaw, IN

Efthimiadis-Keith, H., 2004, The enemy is within, Brill Academic Publishers, Boston MA.

Efthimiadis-Keith, H., 2011, 'On the Egyptian origin of Judith or Judith as Anath-Yahu', Journal of Semitics 20(1), 300-322.

Elwell, W.A. \& Comfort, P.W., 2001, Tyndale Bible dictionary: Tyndale reference library, Tyndale House Publishers, Wheaton. (Logos Research Systems).

Enslin, M.S., 1972, The book of 'Judith': Greek text with an English translation, commentary and critical notes, Brill, Leiden.
Everaert-Desmedt, N., 2007, Semiotique du recit, De Boeck, Bruxelles.

Grabbe, L.L., 2004, A history of the Jews and Judaism in the Second Temple period: A history of the Persian province of Judah, Clark International, London.

Harrington, D.J., 1999, Invitation to the apocrypha, Eerdmans, Grand Rapids, MI.

Henault, A., 1983, Narratologie semiotique generale: Les enjeux de la Semiotique 2 Presses Universitaires de France, Paris.

Hobyane, R.S., 2012, 'A Greimassian semiotic analysis of Judith', DLit et Phil dissertation, School of Ancient Language and Text Studies, North-West University, Potchefstroom.

Hobyane, R.S., 2014, 'The compositional/narrative structure of Judith: A Greimassian perspective', Old Testament Essays 27(3), 896-912.

Jordaan, P.J., 2009a, 'The pendulum is never static: Jesus Sira to Jesus Christ on women in the light of Judith, Susanna and LXX Esther', HTS Teologiese Studies/ Theological Studies 65(1), 180-183. http://dx.doi.org/10.4102/hts.v65i1.167

Jordaan, P.J., 2009b, Reading 'Judith' as therapeutic narrative, Brill, Leiden. (Vetus Testamentum Supplement 127).

Kaiser, O., 2004, The Old Testament apocrypha: An introduction, Hendrickson, Peabody, MA.

Kanonge, D.M., 2009, 'The emergence of women in the LXX apocrypha', PhD thesis, Faculty of Theology, North-West University, Potchefstroom.

Kay, D.M., 1913, 'Judith', in R.C. Charles (ed.), The apocrypha and pseudepigrapha of the Old Testament, pp. 638-651, Clarendon, Oxford.

Liddell, H.G. \& Scott, R., 2002, A Greek-English lexicon, abr. edn., Oxford University Press, New York, NY.

Louw, J.P. \& Nida, E.A., 1996, Greek-English lexicon of the New Testament: Based on semantic domains, 2nd edn., United Bible Societies, New York, NY. (Logos Research Systems). [CD].

Martin, B. \& Ringham, F., 2000, Dictionary of semiotics, Cassel, London.

Nickelsburg, G.W., 2005, Jewish literature between the Bible and the mishnah, 2nd edn., Fortress, Minneapolis, MN.

Raja, R.J., 1998, 'Judith', in W.R. Farmer (ed.), The international Bible commentary: A catholic and ecumenical commentary for the twenty-first century, pp. 696-706, The Liturgical Press, Collegeville, PA.

Roitman, A.D., 1992, 'Achior in the book of Judith: His role and significance', in J.C. Vanderkam (ed.), No one spoke ill of her: Essays on 'Judith', pp. 31-46, Society of Biblical Literature, Atlanta, GA.

Swanson, J., 1997, Dictionary of biblical languages with semantic domains, Logos Research Systems, Oak Harbor. [CD].

Wennel, K.J., 2007, Jesus and land: Sacred and social space in Second Temple period, Clark, Londen.

Wohrle, J., 2011, 'Israel's identity and the threat of the nations in the Persian Period', in O. Lipschits, G.N. Knoppers \& M. Oeming (eds.), Judah and the Judeans in the Achaemenid Period: Negotiating identity in an international context, pp. 153-172, Eisenbrauns, Warsaw, IN. 